annual budget, instead of being credited to the district revenues would have come to the Department. The latter would have had long ago sufficient strength to put in force the urgent variety of work which, the report shows, is now being attempted. If it is necessary to train the forester for his duties, it follows that they cannot be carried out, nor even fully understood, by other elements of the administration. The striking example is the collection of the valuable gurn arabic by the people under the ægis of the civil administration to which, as has been said, is credited this valuable revenue. It brings to mind the old days, during two-thirds of the last century in Madras, when the revenue authorities considered that the forest officer could only exercise his duties in the heavy timber forests, chiefly situated in the western half, and that he had no jurisdiction in the scrub forests in the eastern half of the Presidency, the produce of which was credited to the district revenue with no supervision over its collection. The points of view of the GovernorGeneral and the Secretary of State for India in this matter were at length accepted by Madras, and all forests and their products, including timber-producing or scrub valuable for firewood and grazing and some other minor products, were placed under the Forest Department and all revenues therefrom credited to that Department. It is not too much to believe that, had the gum arabic product been placed under the Forest Department in the Sudan even as late as 1932, the methods of collection and regulation of the so-called 'gardens' would have long ago been under a working plan and a larger annual revenue could be now realized (see para. 179 of the report).

With the comparatively recent expansion of the work during 1951-52, 496,469 feddans of new reserves were gazetted, bringing the total of reserved forest up to 722,553 feddans $(1,173$ square miles), which seems very little to show for fifty years of work. But taking areas under reservation, the area totals 3,051 square miles, representing 0.314 per cent of the total area of the Sudan. It is noted in the report that Uganda has already more than 7 per cent of reserved forest. In knowledgeable quarters it is judged that 15 per cent of well-distributed forests is none too much for safety in an arid tropical country. A very considerable amount of planting has been carried out during the year, a large planting campaign having been organized.

The staff of the Department amounts to twenty officers (two under training in the United Kingdom) and seventy-six in the subordinate ranks, other than forest guards, who are not mentioned. If this staff was doubled it would scarcely be able to carry out all the duties facing a Forestry Department entrusted by its Government to undertake all the forestry work in the country. Enumeration surveys of all forests of commercial value, in which saw-mills appear to be multiplying, and, perhaps even more important, investigations into the ownership of supplies from which the large demands for firewood and charcoal are being obtained, would appear to be urgent. For example, one reads in the report on this subject: "For the southern division the Conservator writes of the increased prosperity in Khartoum Province, reflected in much building with an accompanying increase in the demand for firewood to burn the bricks. The demand far exceeded the supply of firewood imported by the Department into Khartoum Province on rail, with the result that the illicit cutting of desert 'scrub' forest showed an unwelcome increase, although no widespread devastation took place." Who is to be the ultimate sufferer through the "illicit cutting of the desert 'scrub' forest"? Moreover, who is the authority directly responsible? Is it the Forestry Department?

In the seventies of the last century a somewhat similar situation arose in the so-called rukhs in the Punjab plains, covered by a desert scrub, on account of its use for firewood. The newly building railways demanded wood fuel for running the engines and wished to have the exclusive use of the scrub; the calculations of the possible available amounts included digging out and utilizing the roots, thus ensuring as resultant desert. This was prevented by placing the management of the rukhs under the management of the Forest Department, which, as the Secretary of State said, had been brought into the administration and trained for the purpose of undertaking this type of work. $\quad$ E. P. SteBbing

\section{ROBERT JAMESON AND THE ROYAL SCOTTISH MUSEUM, EDINBURGH}

A PAPER by Mr. V. A. Eyles on "Robert Jameson and the Royal Scottish Museum", published in the April issue of Discovery, is particularly appropriate in view of the centenary this year of the Royal Scottish Museum, Edinburgh, for it was through Jameson's enthusiastic labours in the College Museum that eventually it attained such a status that it was taken over by the State. In a foreword, Mr. Eyles describes the origin of the University of Edinburgh and its relationship to the civic authorities. He then records the circumstances of the establishment of the chair of natural history and its progress under Dr. Robert Ramsay, Dr. John Walker and Robert Jameson, who succeeded in 1804 .

The professor of natural history was ex officio keeper of the Museum, and Jameson, in addition to a long and distinguished career as a naturalist, was also zealous in his care of the collections. Eventually geology became his chief subject, and he was caught up in the great Huttonian-Wernerian controversy. He studied under Werner in the mining town of Freiburg for nearly two years; and Eyles records that he "absorbed uncritically all that he [Werner] had to say" and eventually became the greatest protagonist for Wernerism in Britain. But his enthusiasm for geology did not mean the neglect of the other branches of natural history, for he lectured on meteorology, hydrology, mineralogy, geology, botany and zoology-truly a formidable list. The general impression among his students, including Charles Darwin, was that the lectures were rather dull but accurate, and unrelieved by any humour_or figures of speech.

As a museum man, Jameson experienced all the trials of a present-day curator, including lack of accommodation and funds. In 1852 Jameson prepared a report on the Museum, and eventually the collections were accepted by the State in $\mathbf{1 8 5 4}$. The foundation-stone of the Royal Scottish Museum in Chambers Street was laid by the Prince Consort in 1871. All interested in the history of geological studies and their influence on contemporary thought are indebted to $\mathrm{Mr}$. Eyles for his painstaking paper. 